\title{
Mapping the implementation of the rapid HIV test in the Family Health Strategy: the nurses' perspective*
}

\author{
Cartografia da implementação do teste rápido anti-HIV na Estratégia Saúde da Família: \\ perspectiva de enfermeiros
}

\author{
Mapeo de la aplicación de la prueba rápida del anti-VIH en la Estrategia Salud de la Familia: \\ perspectiva de enfermeros
}

\|lisdayne Thallita Soares da Silva ${ }^{1}$ Cecília Nogueira Valença ${ }^{1}$ Richardson Augusto Rosendo da Silva ${ }^{1}$

1. Universidade Federal do Rio Grande do Norte. Natal, RN, Brazil.
Corresponding author:

Cecília Nogueira Valença.

E-mail: cecilia_valenca@yahoo.com.br

Submitted on $02 / 10 / 2017$

Accepted on $07 / 31 / 2017$.

DOI: 10.1590/2177-9465-EAN-2017-0019

\begin{abstract}
Objective: To analyze the implementation of the rapid HIV test in the Family Health Strategy (FHS) from the perspective of nurses. Method: A qualitative study was performed with $13 \mathrm{FHS}$ nurses between March and June 2015 using a semi-structured interview. The data were analyzed by symbolic cartography and Bardin's thematic analysis. Results: The nurses projected to the center of the map: lack of test kits, insufficient time for training, speed of the test result and excessive activities. In the periphery, they placed aspects related to the physical space, the lack of participation of other professionals in the training, the ease of performing the test and breaking the news of positive HIV diagnoses. Conclusion and implications for practice: An adequate supply of test kits, tests more widely available to the entire population and training of other members of the FHS team are required. This study supports improvements in the nursing practice of rapid HIV testing.
\end{abstract}

Keywords: Nursing; HIV; Family Health Strategy.

\section{Resumo}

Objetivo: Analisar a implementação do teste rápido anti-HIV na Estratégia Saúde da Família (ESF) na perspectiva de enfermeiros. Método: Pesquisa qualitativa com 13 enfermeiros da ESF, entre março e junho de 2015, por meio de entrevista semiestruturada. Os dados foram analisados pela cartografia simbólica e análise temática de Bardin. Resultados: Os enfermeiros projetaram para o centro da cartografia: insuficiência dos insumos de testagem; tempo insuficiente da capacitação; rapidez no resultado do exame; e sobrecarga de atividades. Na periferia, aspectos relacionados ao espaço físico; à ausência de participação de outros profissionais na capacitação; ao fácil manuseio do teste; e à revelação do diagnóstico positivo do HIV. Conclusão: São necessários fornecimento adequado de testes para as unidades, ampliação da oferta do teste e expansão da capacitação para outros membros da equipe da ESF. O estudo fornece subsídios para melhorar a prática do enfermeiro na testagem rápida anti-HIV.

Palavras-chave: Enfermagem; HIV; Estratégia Saúde da Família.

\section{Resumen}

Objetivo: Analizar la implementación de prueba rápida anti-VIH en la Estrategia Salud de la Familia (ESF) en la perspectiva de los enfermeros. Método: Investigación cualitativa con 13 enfermeros de ESF, realizada entre marzo y junio de 2015 por medio de entrevista semiestructurada. Los datos fueron analizados por cartografía simbólica y análisis temático de Bardin. Resultados: Los enfermeros proyectaron para el centro de la cartografía: insuficiencia de insumos de prueba; tiempo insuficiente de capacitación; rapidez en el resultado del examen; y sobrecarga de actividades. En la periferia: espacio físico, ausencia de participación de otros profesionales en la capacitación, fácil manejo de la prueba y revelación del diagnóstico positivo de VIH. Conclusión e implicaciones para la práctica: Se necesitan kits de pruebas apropiadas para las unidades, expansión de la prueba y ampliación de la formación a otros miembros de ESF. El estudio proporciona subsidios para mejorar la práctica de prueba rápida anti-VIH.

Palabras clave: Enfermería; VIH; Estrategia Salud de la Familia. 


\section{INTRODUCTION}

The incidence of human immunodeficiency virus (HIV) infection has caused concern worldwide ever since the first cases of AIDS diagnosed in the early 1980s. Today, it is characterized as a pandemic. HIV is important because of the changes it causes in the individual's life, especially when the AIDS progresses. This syndrome affects the immune system and can lead to opportunistic infections that not infrequently result in death. ${ }^{1}$

Despite the difficulties in coping with the pandemic, undeniable advances have been achieved resulting in more knowledge, and better treatment and prevention of HIV infection and AIDS. As a result of successful experiences, current policies focus on challenges such as achieving control and ending the pandemic by 2030 , which will produce major benefits to global health and the economy. ${ }^{2}$

In this context, the goal of the 90-90-90 target is to intensify treatment in people with HIV. This goal means that by $2020,90 \%$ of all people living with HIV will know they have the virus, $90 \%$ of all people with diagnosed HIV infection will receive antiretroviral therapy without interruption and $90 \%$ of all people receiving treatment will have viral suppression. ${ }^{3}$

One of the most important aspects for the implementation of this action is the early diagnosis of HIV infection, which highlights the need to expand coverage of HIV testing and the need for continuity of testing services. ${ }^{4}$ In Brazil, testing and counseling practices are paramount in prevention programs, and rapid tests are used to increase the population's access to the diagnosis of HIV infection. ${ }^{5}$

These diagnostic tests can be carried out in different locations, including within the Family Health Strategy (FHS) as an initiative of the Ministry of Health to redirect the care model of primary health care provided by the Brazilian National Health Service (SUS). ${ }^{6}$ The Brazilian HIV/AIDS control policy prioritizes the FHS as the coordinator and provider of care and stimulates the decentralization process of care for people living with HIV/AIDS to this level of care, in order to increase access to both the diagnosis and treatment related to the virus in family health units (FHUs). ${ }^{7}$

These units are characterized as the entry point of individuals into the public health system; they should receive the patients and are responsible for diagnosis and treatment, as well as providing referrals to specialist centers, when necessary. The HIV test should be offered in the FHUs in accordance with the principles of universality and accessibility of health care, and performed with the consent of the individual. ${ }^{8}$

Although the FHS is conducted by multiprofessional health teams, nurses are considered an important member for the consolidation of the strategy as a health policy, acting as the protagonist in the actions of planning, organization and operationalization of this service. ${ }^{9}$ The implementation of rapid HIV testing in the FHS is an opportunity for the nurse to assist subjects by clarifying doubts, identifying and reducing vulnerabilities, as well as deconstructing prejudiced beliefs about HIV/AIDS. ${ }^{10}$
It should be noted that rapid HIV testing within the FHS is an action that contributes to the identification of the serological status so that treatment with antiretroviral drugs can be started immediately, thus helping people living with HIV/AIDS to achieve undetectable viral loads, thereby reducing the risk of virus transmission in the population.

In this sense, rapid HIV testing strengthens the treatment strategy as prevention against HIV/AIDS, which is considered one of the most important factors in the current health policy to combat the epidemic in Brazil. ${ }^{7}$ An analysis of the implementation of the test in the FHS from the nurses' perspective is essential to verify if there is an alignment between what was planned by the Department of Sexually Transmitted Diseases, AIDS and Viral Hepatitis and what is being achieved in the health services, thus justifying the present study.

Hence, analysis will support discussions regarding possible interventions and adaptations that will improve the performance of rapid HIV testing within the scope of the FHS. Therefore, this study aims to analyze the implementation of rapid HIV testing in the FHS from the nurses' perspective.

\section{METHOD}

This is a descriptive and exploratory study with a qualitative approach. The location for the development of the research were the FHUs of the rural and urban zones of twelve municipalities of the Fourth Regional Health Management District of the State of Paraíba, Northeastern Brazil. This region covers the following municipalities: Baraúna, Barra de Santa Rosa, Cubati, Cuité, Damião, Frei Martinho, Nova Floresta, Nova Palmeira, Pedra Lavrada, Picuí, Seridó and Sossego. ${ }^{11}$ This region was chosen to carry out the research because it was a pioneer in the implementation of rapid HIV testing in FHUs in the State of Paraiba.

The study participants were FHU nurses. The strategy was to use complete data collection ${ }^{12}$ from all the FHUs, so that all the nurses who perform the rapid HIV tests in the FHS of these municipalities, a total of 16 professionals, would be enrolled in the study.

The inclusion criteria were as follows: nurses who were performing rapid HIV tests in the FHS and worked in the municipalities of the Fourth Regional Health Management District of Paraiba. The sample was limited by the exclusion criterion: nurses who were away from work due to medical leave or vacations, during the period in which the data collection was performed. Thus, thirteen professionals from nine municipalities were interviewed.

Data collection took place from April to June 2015 using a semi-structured interview script that enabled the general data of the participants to be obtained, such as gender, age, marital status, time of service and experience performing HIV testing in the FHS. The guiding questions were focused on the facilities and difficulties experienced by these professional to perform rapid HIV testing, the structural aspects of the service (physical space to carry out the tests, the storage space of the test kits, 
availability of test kits) and training to perform the rapid HIV test. The interviews were recorded and transcribed.

The data were analyzed using the method of symbolic cartography of Boaventura de Sousa Santos, and maps (modes of imagining and representing real space) were constructed in the form of frames using scale, projection and symbolization mechanisms. ${ }^{13}$

A scale expresses the degree of detail of the representation and delimits the social space that is being analyzed. The larger the scale, the greater the degree of detail. ${ }^{13}$ In this study a large scale was used, represented by the municipalities where the FHUs were located. With respect to projection, all maps have a center, a place to which a privileged position is assigned with the remaining spaces (periphery) being dispersed around the center. ${ }^{13}$ In symbolization, the symbols were represented by the respondents' statements. ${ }^{13}$

The thematic analysis of Bardin was used in the construction phase of the cartographic projection. This thematic analysis identifies nuclei of meaning in a communication by analyzing meanings that verify the significance of the presence or frequency of these nuclei in respect to the object being analyzed..$^{14}$ In this sense, the organization of the content was carried out from the codification of the data, categorization of data and interaction of thematic nuclei. ${ }^{14}$

Thus, the most frequently mentioned elements, that is, those mentioned by more than $50 \%$ of respondents, were placed in the center of the $\mathrm{map}^{13}$ in the form of categories. These categories were insufficient rapid HIV tests $(100 \%)$, insufficient time for training $(84.61 \%)$, speed of the test result $(100 \%)$, lack of test kits to operationize the testing process $(100 \%)$, and excessive activities (92.30\%).

On the other hand, the less common elements, i.e. mentioned by less than $50 \%$ of the respondents, were placed in the periphery. ${ }^{13}$ These were a room to perform the test and storage space for the test $(38.46 \%)$, lack of participation of other types of professionals in training $(30.76 \%)$, the simplicity of the test $(38.46 \%)$, fewer patients refused to take the test $(23.07 \%)$, and breaking the news of positive HIV test results (38.46\%).

To guarantee anonymity, participants names were replaced by the letter I (interviewee) followed by a number corresponding to the sequence of the interviews $(11,|2 \ldots| 13)$. In a similar way, the names of the municipalities were replaced by the letter $\mathrm{M}$ (municipality) followed by a randomly chosen number (M1, M2 ... M9).

This article is part of a master's dissertation, which was approved by the Research Ethics Committee of the Federal University of Rio Grande do Norte (no 39639314.7.0000.5537; Decision No 977,003).

\section{RESULTS}

Twelve female professionals and one male professional were enrolled in this research. The ages of the nurses ranged from 26 to 55 years, the time in the service ranged from one to 29 years, and their experience performing rapid HIV tests in the FHS ranged from less than one year to three years.
The analysis of the interviews allowed the construction of four maps. The nuclei of meaning that appeared most frequently in the respondents' discourses were projected to the center of the map in the form of categories while the less frequent nuclei were projected to the periphery. The nurses' statements about the basic infrastructure (physical space to perform the tests, storage space for the test kits and the availability of tests) used for rapid HIV testing in the FHS resulted in the construction of Map 1.

All professionals interviewed reported having received training to perform rapid HIV tests in presential situations. Map 2 shows the quality of this training.

Insufficient time for training produces weaknesses in the approach to the patient undergoing the test. Some aspects go beyond the technique, such as preparing the professional for counseling, especially in cases of patients with positive results, and in respect to referring patients to a specialist center. Also notable is the participation of nurses in training and the absence of other types of professionals, especially as testing is characterized as a multiprofessional procedure.

Regarding the facilities experienced by nurses in HIV testing within the context of the FHS, the respondents' statements enabled the construction of Map 3.

In addition to the facilities, the nurses had trouble to implement the rapid HIV test in the FHS, as can be observed in Map 4

According to Map 4, several factors make it difficult to implement rapid HIV testing under the FHS in the region. There are situations where testing is not performed because of the nurse's fault, or because there are too few test kits to meet the demand. In addition, the excess of activities is worrying in that it causes a nurse to stop divulging the rapid HIV test to the population because of lack of time related to the excess of other activities carried out within the FHS.

\section{DISCUSSION}

Regarding infrastructural aspects, not all municipalities have a specific place to store the tests and so they are stored in non-exclusive refrigerators, which is contrary to the legal recommendation, which proposes that rapid HIV test kits should be stored in refrigerators or in an air-conditioned room, thus respecting the manufacturers' temperature guidelines of between $2^{\circ} \mathrm{C}$ and $30^{\circ} \mathrm{C} .{ }^{15}$ This setting makes it difficult to monitor the storage temperature of the test and may affect the reliability of the test, indicating that structural problems may negatively interfere with the performance of the test.

Regarding the room, there is no need for it to be just for rapid HIV testing, but the patient's privacy should be guaranteed. Thus, the place where the procedure is performed must have the minimum facilities to provide a comfortable environment and ensure the wellbeing of both the user and the professional. ${ }^{16}$

The interviewed nurses state that the lack of test kits significantly interferes with the operationalization of the service. In mapping, the insufficiency of the rapid test kits involves two aspects, namely: too few test kits and the absence of test kits from 
Map 1. Mapping of the basic infrastructure used to implement rapid HIV testing in the FHS according to the nurses (Paraíba, 2015)

\begin{tabular}{|c|c|}
\hline Scale & $\begin{array}{c}\text { Symbolization } \\
\text { (Voices of the respondents) }\end{array}$ \\
\hline M1 & $\begin{array}{l}\text { I do not have a room to perform the test. I do not have the storage space. I get the test kits } \\
\text { from only one lab at a time. It is rare to see tests from different laboratories at the same } \\
\text { time. The correct would be this. At the moment, I work with only one kind of test. So, if there } \\
\text { is a positive result, I repeat with the same test. I have no choice (I10). }\end{array}$ \\
\hline M2 & $\begin{array}{l}\text { I have no problems with the room. I have privacy. I stay in the room alone with the patient. } \\
\text { The tests are stored in the pharmacy refrigerator. In the refrigerator that only has insulin. } \\
\text { The biggest problem in the structure is the lack of tests. We sent worksheets to management } \\
\text { every month, but I have not received any tests for five months (I8). }\end{array}$ \\
\hline \multicolumn{2}{|r|}{ Projection } \\
\hline Center & Periphery \\
\hline Two few rapid HIV test kits & A room to perform the test and storage space for the test \\
\hline
\end{tabular}

Map 2. Mapping of the training received to perform rapid HIV tests in the FHS according to the nurses (Paraíba, 2015)

\begin{tabular}{|l|l|}
\hline Scale & $\begin{array}{c}\text { Symbolization } \\
\text { (Voices of the respondents) }\end{array}$ \\
\hline M3 & $\begin{array}{l}\text { I thought the time of training was too short. It should have been longer. A lack of attention } \\
\text { paid to the counseling part of training. On how to talk to the patient with positive or negative } \\
\text { test results. There was also a lack of discussion about patient referral in the case of a positive } \\
\text { result. I do not know the procedure that should be followed; I do not know where to send the } \\
\text { patient (I2). } \\
\text { The training was satisfactory about testing, about the technique itself. But, related to } \\
\text { counseling, it was not enough. I was the only one from my municipality to participate in the } \\
\text { training. I think they should have sent other professionals to participate such as the social } \\
\text { worker and the psychologist to give support (I5). }\end{array}$ \\
M4 Projection \\
\hline Center
\end{tabular}

different manufacturers in stock at the same time. This situation has serious implications for timely access to HIV diagnoses for populations in the FHS of the region, as a single test is not sufficient to confirm a diagnosis. ${ }^{7}$ In this situation, the test functions as a screening test, losing one of its main advantages: to provide the diagnosis of HIV almost immediately without the need for serology. ${ }^{7}$

The reduced quantity of tests makes it difficult for the population to have access. Currently, there is an increase in the number of HIV cases among heterosexuals, women and the low-income population. However, there are high rates of the disease among social groups historically affected by the epidemic, such as men who have sex with men, drug users and sex workers, ${ }^{17}$ pointing to the need for FHS to incorporate universal access to diagnosis, in addition to ensuring equity in the care provided to the most vulnerable populations. The provision of rapid HIV testing in community-based services contributes to the early detection of the virus, especially in populations that have more difficulties to access healthcare. ${ }^{18}$
In this sense, the importance of management in the process of implementing the rapid HIV test in the FHS is clear, particularly regarding the establishment of an adequate infrastructure to make all those who seek the service feel relaxed, taking into account privacy, ethical aspects and respect for the different demands required by users. The advantages provided by the rapid HIV test requires a minimum structure such as adequate storage space, kits of different brands and in sufficient quantity.

The statements of the interviewees also highlight problems related to the training received for rapid HIV testing. It can be seen that the time for training was not enough to leave the professional prepared to deal with the other stages involved in the testing process, such as counseling and the referral of the patient with a positive HIV result.

In general, specific training to care for drug users who have HIV is restricted to specialized centers. ${ }^{19}$ This situation and the professionals' lack of preparation regarding stigma associated with the infection leads to the discontinuation of care when these patients are treated in other SUS services..$^{20}$ One study found that 
Map 3. Mapping of facilities experienced by nurses in the development of rapid HIV testing (Paraíba, 2015)

\begin{tabular}{|c|c|}
\hline Scale & $\begin{array}{c}\text { Symbolization } \\
\text { (Voices of the respondents) }\end{array}$ \\
\hline M5 & $\begin{array}{l}\text { Not every municipality provides a laboratory to perform the HIV test. We, for example, send them to } \\
\text { another city and there is a demand from other municipalities in that city. When will the exam [results] } \\
\text { arrive? The simplicity is this: you identify something in time.This enables early interventions. That's the } \\
\text { purpose of quick tests. Otherwise, it would not be a rapid test (I6). }\end{array}$ \\
\hline M6 & $\begin{array}{l}\text { The simplicity is that there is no more rejection among the patients. When I offer, they already ask me: } \\
\text { what day can I do it? So this I think is important because I have } 22 \text { years of experience and I've never } \\
\text { seen this before. Today they no longer have any resistance to take the test (II1). }\end{array}$ \\
\hline \multicolumn{2}{|r|}{ Projection } \\
\hline Center & Periphery \\
\hline Fast exam results & $\begin{array}{l}\text { Easy to perform the test } \\
\text { Less refusal by the patient to take the test }\end{array}$ \\
\hline
\end{tabular}

Map 4. Mapping of the difficulties experienced by nurses in the development of rapid HIV testing (Paraíba, 2015)

\begin{tabular}{|c|c|}
\hline Scale & $\begin{array}{l}\text { Symbolization } \\
\text { (Voices of the respondents) }\end{array}$ \\
\hline M8 & $\begin{array}{l}\text { The difficulty is that the nurse is alone to perform the test. There is a high demand for few } \\
\text { professionals. In addition, the number of tests is limited. It is not possible to contemplate a } \\
\text { larger number of vulnerable patients (I13). }\end{array}$ \\
\hline M9 & $\begin{array}{l}\text { The difficulty is the short time we have because of the other activities carried out in the } \\
\text { FHS. Therefore, here in the municipality, we just test pregnant women. They asked us to tell } \\
\text { the public that the unit has a quick test, but we do not because we do not have time to do } \\
\text { it. It's too much, the demand is great. In addition, the number of tests is small (I4). }\end{array}$ \\
\hline M2 & $\begin{array}{l}\text { The difficulty I think is telling the patient that he has HIV. Most people think it's the end. } \\
\text { That there's no way (E8). }\end{array}$ \\
\hline \multicolumn{2}{|r|}{ Projection } \\
\hline Center & Periphery \\
\hline $\begin{array}{l}\text { Too few tests to operationalize } \\
\text { the testing process } \\
\text { Too many activities }\end{array}$ & Breaking the news of HIV positive test results \\
\hline
\end{tabular}

health professionals have difficulty dealing with the subjectivity of the health-disease process and assuming a reflexive practice with the patient. ${ }^{5}$ Faced with this situation, they sometimes transfer the responsibility of informing the diagnosis of HIV to the psychologist. ${ }^{20}$

Thus, a policy of permanent education in the health service that addresses not only the technical procedures of testing, but also the psychological, emotional and social aspects, which permeate HIV/AIDS is necessary. This education model seeks to construct critical-reflexive and participatory actions in the teaching and learning processes. ${ }^{21}$ It also enables the restructuring of professionals' knowledge based on problematization and internal demands of their work practices. ${ }^{21}$

In addition, the participation of other professional categories in the training to perform rapid HIV testing in order to contribute to an effective implementation of the test in the service through teamwork should be seen as important. A study carried out in a Government Health Clinic in Rio de Janeiro showed that teamwork in the FHS context allows a better communicative and collaborative practice in which different professionals value each other's work and share common goals. ${ }^{22}$

Regarding the facilities for the implementation of the rapid HIV test in the FHS, the reduction in the delay for HIV results represents a significant advance in the fight against the HIV/ AIDS epidemic, ${ }^{23}$ since the lack of agility in giving the test results using conventional methodologies is common in many parts of Brazil. In Rio de Janeiro, the time to deliver test results attained using the laboratory method ranged from 7-40 days, while with the rapid HIV test the delay is 15 minutes. ${ }^{24}$

Thus, rapid HIV testing has brought significant changes in time management, and in respect to the uncertainties and anxieties arising from risk behaviors. This has given citizens almost immediate access to their serostatus, the possibility of prompt drug treatment and improved follow-up of seropositive individuals, which has had positive impacts in the fight against HIV/AIDS. ${ }^{23}$ 
In shelters for female victims of domestic violence in the United States of America, it was found important for these women that the results were given within a few minutes after completing the test; the necessity to wait for several weeks for a result causes stress. ${ }^{18}$ Access to early diagnosis improves the survival expectations of the seropositive individual, with delayed testing, in many cases, resulting in missed opportunities to prevent comorbidities, which may culminate in the death of the patient. ${ }^{25}$

A survey conducted in the USA showed high mortality rates in over 50-year-old adults most of which were associated with late diagnosis. ${ }^{26}$ In addition, the importance of screening the entire population was found to be an effective way to promote the early detection of HIV/AIDS. ${ }^{26}$ Of the strategies considered to ensure the timely identification of seropositive patients is providing HIV testing in the routine of all health services, including primary health care services. ${ }^{27}$

The space of the FHS favors a reduction in the refusal of patient to perform the test, as was found in the current research. The FHS, as a way to reorganize the health care model, signals a social intervention approach, no longer focused on medical treatment knowledge, but focused on education, and the promotion and protection of health. ${ }^{28}$

Another facility pointed out by nurses in the study region was that the rapid HIV testing was easy to perform. The simple method is one of the aspects that characterize it as a good alternative in the diagnosis of HIV, since conventional laboratory tests are operationally complex, requiring specialized professionals and an appropriate laboratory infrastructure. ${ }^{23}$ On the other hand, rapid HIV testing does not require a specialized laboratory or professionals, or specialized collection and transportation, which facilitates the individual's access to the test. ${ }^{23}$

However, the limited number of tests, identified as one difficulty experienced by the nurses in this study, leads to many professionals not attending the spontaneous demand and to prioritizing certain groups, such as pregnant women. The diagnosis of HIV during pregnancy is one of the strategies of the Ministry of Health to reduce vertical transmission, since it allows interventions to be established during this phase and during childbirth. ${ }^{10}$ However, other population groups are excluded due to lack of testing in the $\mathrm{FHU}$ of the region.

The discourses also project the excess of activities carried out in the FHU to the center. In this health service, the work of nurses is planned according to actions pre-established by the Ministry of Health in the area of child health, women's health, control of hypertension and diabetes mellitus, control of tuberculosis, among others. ${ }^{29}$

Moreover, activities involving bureaucratic coordination and service management, meetings in the Health Department, and training community health agents and nursing assistants are also carried out. ${ }^{30}$ In this sense, the flexibility of the FHS work process to incorporate other demands that go beyond nationally delimited priorities is still a challenge. ${ }^{31}$

The insertion of the rapid HIV test in the routine of the FHS implies a reorganization of the work process of the team and of the service as a whole, since this practice requires paying attention to the time of service, and reviewing the demand, functions and activities within the service. It is also worth noting that few rapid HIV tests are performed in the study region because it consists of twelve municipalities and only 13 nurses perform the rapid HIV test; this impairs the effectiveness of the decentralization of testing in the area.

In this region, the communication of a positive HIV result to the patient causes difficulties in the implementation process of rapid HIV testing in the FHS. Despite all the advances in coping with the epidemic, people with AIDS experience a complex reality, because the disease is still seen by the population as a death threat, causing fear, stigma, and discrimination and, in many countries, marginalization. ${ }^{32}$

Behavior of denial are often observed in people with HIV/AIDS as a reflection of the fear of revealing to society the condition of being HIV positive. This picture is associated with the representations of a contagious and lethal disease that were constructed at the beginning of the epidemic and that continue until today. ${ }^{33}$

Thus, the outcome of a positive test result produces significant repercussions in the person's life and produces specific health care demands. Disclosure of the diagnosis requires trained counseling to help the HIV-positive person find a way to address the news. ${ }^{34}$

This study presents the fact that it interviewed only nurses as a limitation. In this sense, it is necessary to expand knowledge by developing future studies that consider the perspectives of both FHS users and managers, as important structural difficulties were found in the process of implementing the rapid HIV test in the FHS.

\section{CONCLUSION}

This study analyzed the implementation of rapid HIV test in the FHS of the Fourth Regional Health Management District of Paraíba. Problems related to the availability of test kits in the region are a barrier to the population's access to testing in FHUs. Thus, it is necessary to plan and work together with the Ministry of Health, and the State and Municipal Health Departments to provide a sufficient number of test kits for these services, in order to avoid the exclusion of certain population groups.

There is a need to expand the offer of the test to the non-pregnant population, in order to favor, through local actions, the global response against the HIV/AIDS epidemic. This requires, in addition to an adequate supply of test kits, training of other team members (nursing assistants, doctors, dentists) through the implementation of a permanent education policy in the FHU and the organization of teamwork, providing the diagnosis of HIV at the first contact with patients.

In addition, through active searches, community health agents can participate in the dissemination and capture of other FHU users to perform the test. The approach to HIV-positive subjects can be improved through the implantation and support of Family Health Support Centers and cooperation with the network of specialized services integrated in a multidisciplinary work centered on the user. 
Through this research, it was possible to recognize potentialities and fragilities in the implementation of rapid HIV testing in the FHS, providing support to stimulate reviews and changes in this process, in order to improve the nursing practice and to promote an effective expansion of HIV therapy in primary health care.

\section{REFERENCES}

1. Silva JVF, Nascimento Júnior FJM, Rodrigues APRA. Fatores de não adesão ao tratamento antirretroviral: desafio de saúde pública. Ciênc Biol Saúde [Internet]. 2014 May; [cited 2015 Sep 5]; 2(1):165-75. Available from: https://periodicos.set.edu.br/index.php/fitsbiosaude/ article/view/1193/772

2. Dieffenbach CW, Fauci AS. Thirty years of HIV and AIDS: future challenges and opportunities. Ann Intern Med [Internet]. 2011 Jun; [cited 2015 Sep 2]; 154(11):766-71. Available from: http://annals.org/article. aspx?articleid=746972. DOI: 10.7326/0003-4819-154-11-20110607000345.

3. Organização Mundial de Saúde. Programa Conjunto das Nações Unidas sobre HIV/AIDS. 90-90-90: uma meta ambiciosa de tratamento para contribuir para o fim da epidemia de AIDS [Internet]. Genebra: Programa Conjunto das Nações Unidas sobre HIV/AIDS; 2015. 38 p. [cited 2016 Set 5]. Available from: http://unaids.org.br/wp-content/ uploads/2015/11/2015_11_20_UNAIDS_TRATAMENTO_META_PT_ v4_GB.pdf

4. Montaner JS. Treatment as prevention: toward an AIDS-free generation. Top Antivir Med [Internet]. 2013 Jul/Aug; [cited 2015 Aug 10];21(3):1104. Available from: https://www.ncbi.nlm.nih.gov/pubmed/23981598

5. Fonseca PL, Iriart JAB. Aconselhamento em DST/Aids às gestantes que realizaram o teste anti-HIV na admissão para o parto: os sentidos de uma prática. Interface Comun Saúde Educ [Internet]. 2012 Apr/Jun [cited 2015 Ago 15]; 16(41):395-407. Available from: http://www.scielosp. org/pdf/icse/v16n41/a09v16n41.pdf

6. Garuzi M, Achitti MCO, Sato CA, Rocha AS, Spagnuolo RS. Acolhimento na Estratégia Saúde da Família: revisão integrativa. Rev Panam Salud Pública [Internet]. 2014 Feb; [cited 2016 Nov 16]; 35(2):144-9. Available from: http://www.scielosp.org/pdf/rpsp/v35n2/a09v35n2.pdf

7. Ministério da Saúde (BR). Secretaria de Vigilância em Saúde. Departamento de DST, AIDS e Hepatites Virais. Caderno de boas práticas em HIV/aids na atenção básica [Internet]. Brasília (DF): Ministério da Saúde; 2014. [cited 2016 Nov 17]. Available from: http:// www.aids.gov.br/sites/default/files/anexos/publicacao/2014/56264/_p_ caderno_boas_praticas_pdf_p_32688.pdf

8. Araújo CLF, Aguiar PS, Santos GKA, Oliveira MGP, Câmara LS. A testagem anti-HIV nos serviços de ginecologia do município do Rio de Janeiro. Esc Anna Nery [Internet]. 2014 Jan/Mar; [cited 2016 Nov 16]; 18(1):82-9. Available from: http://www.scielo.br/pdf/ean/v18n1/14148145-ean-18-01-0082.pdf. DOI: 10.5935/1414-8145.20140012

9. Silva VG, Motta MCS, Zeitoune RCG. A prática do enfermeiro na Estratégia Saúde da Família: o caso do município de Vitória/ES. Rev Eletr Enferm [Internet]. 2010; [cited 2016 Nov 16]; 12(3):441-8. Available from: https://www.fen.ufg.br/fen_revista/v12/n3/v12n3a04.htm

10. Silva O, Tavares LHL, Paz LC. As atuações do enfermeiro relacionadas ao teste rápido anti-HIV diagnóstico: uma reflexão de interesse da enfermagem e da saúde pública. Enferm Foco [Internet]. 2011; [cited 2016 Nov 16];2(Suppl):58-62. Available from: http://revista.portalcofen. gov.br/index.php/enfermagem/article/view/83/69

11. Instituto Brasileiro de Geografia e Estatística - IBGE (BR). Cidades: Paraíba [Internet]. Brasília: Instituto Brasileiro de Geografia e Estatística: 2010 [cited 1 Nov 2014]. Available from: http://cidades.ibge.gov.br/xtras/ uf.php?lang=\&coduf=25\&search=paraiba

12. Flick U. Amostragem. In: Flick U. Introdução à Pesquisa Qualitativa. $3^{\text {a }}$ ed. Porto Alegre: Artmed; 2009. p. 118-28.
13. Santos BS. Uma cartografia simbólica das representações sociais: o caso do direito. In: Santos BS. A crítica da razão indolente contra o desperdício da experiência: para um Novo senso comum: a ciência, o direito e a política na transição paradigmática. 6aㅡ ed. São Paulo: Cortez; 2007. p. 197-224.

14. Bardin L. Análise de conteúdo. São Paulo: Edições 70; 2011. 229 p.

15. Ministério da Saúde (BR). Secretaria de Vigilância em Saúde. Departamento de DST, AIDS e Hepatites Virais. Nota Técnica $\mathrm{n}^{\circ}$ 217/2011 - D-DSR-AIDS-HV/SVS/MS. Informações sobre temperatura de armazenamento e transporte dos kits de testes rápidos para HIV e sífilis [Internet]. Brasília (DF): Ministério da Saúde; 2011. [cited 2014 Nov 1]. Available from: http://www.aids.gov.br/sites/default/files/anexos/ legislacao/2012/51115/nt_217_temperatura_de_armazenamento_e_ transporte_d_22766.pdf

16. Esher A, Santos EM, Magarinos-Torres R, Azeredo TB. Construindo critérios de julgamento em avaliação: especialistas e satisfação dos usuários com a dispensação do tratamento do HIV/Aids. Ciênc Saúde Coletiva [Internet]. 2012; [cited 2016 Nov 17]; 17(1):203-14. Available from: http://www.scielo.br/pdf/csc/v17n1/a22v17n1.pdf

17. Silva NEK, Oliveira LA, Sancho LG. Testagem anti-HIV: indagações sobre a expansão da oferta sob a perspectiva do acesso e da construção da demanda. Saúde Debate [Internet]. 2013 Oct/Dec; [cited 2016 Nov 17]; 37(99):636-45. Available from: http://www.scielo.br/pdf/sdeb/ v37n99/a11v37n99.pdf

18. Draucker CB, Johnson DM, Johnson NL, Kadeba MT, Mazurczyk J, Zlotnick C. Rapid HIV testing and counseling for residents in domestic violence shelters. Women Health [Internet]. $2015 \mathrm{Apr}$ [cited 2016 Nov 17]; 55(3):334-52. Available from: https://www.ncbi. nlm.nih.gov/pmc/articles/PMC4401648/pdf/nihms675437.pdf. DOI: 10.1080/03630242.2014.996726

19. Silva LMS, Guimarães TA, Pereira MLD, Miranda KCL, Oliveira EN Integralidade em saúde: avaliando a articulação e a co-responsabilidade entre o Programa Saúde da Família e um serviço de referência em HIV/aids. Epidemiol Serv Saúde [Internet]. 2005 Jun; [cited 2016 Nov 17]; 14(2):97104. Available from: http://scielo.iec.pa.gov.br/pdf/ess/v14n2/v14n2a05.pdf

20. Palácio MB, Figueiredo AC, Souza LB. O cuidado em HIV/AIDS e a Atenção Primária em Saúde: possibilidades de integração da assistência. Psico (Porto Alegre) [Internet]. 2012 Jul/Sep; [cited 2016 Nov 17]; 43(3):350-67. Available from: http://revistaseletronicas.pucrs. br/ojs/index.php/revistapsico/article/view/9816/8237

21. Miccas FL, Batista SHSS. Educação permanente em saúde: metassíntese. Rev Saúde Pública [Internet]. 2014 Feb; [cited 2016 Jan 2] 48(1):170-85. Available from: http://www.scielo.br/scielo.php?script=sci arttext\&pid=S0034-89102014000100170\&lng=en\&nrm=iso

22. Pereira RCA, Rivera FJU, Artmann E. O trabalho multiprofissional na Estratégia Saúde da Família: estudo sobre modalidades de equipes. Interface (Botucatu) [Internet]. 2013 Apr/Jun; [cited 2017 Jul 2] 17(45):327-40. Available from: http://www.scielo.br/pdf/icse/v17n45/ aop0613.pdf

23. Ribeiro FB, Sacramento O. A despistagem do VIH/sida: saúde pública $e$ motivações dos utentes do teste rápido no Nordeste de Portugal. Saúde Soc [Internet]. 2014; [cited 2016 Nov 17]; 23(2):510-22. Available from: http://www.scielo.br/pdf/sausoc/v23n2/0104-1290-sausoc-23-2-0510. pdf. DOI: 10.1590/S0104-12902014000200012

24. Sobreira PGP, Vasconcellos MTL, Portela MC. Avaliação do processo de aconselhamento pré-teste nos Centros de Testagem e Aconselhamento (CTA) no Estado do Rio de Janeiro: a percepção dos usuários e profissionais de saúde. Ciênc Saúde Coletiva [Internet]. 2012; [cited 2016 Nov 17]; 7(11):3099-113. Available from: http://www.scielo.br/pdf/ csc/v17n11/v17n11a25.pdf

25. Martins TA, Kerr LRFS, Kendall C, Freire DG. Testagem para HIV estratégia para a prevenção e o controle da epidemia. Rev Fisioter Saúde Funcional [Internet]. 2014 Aug/Dec; [cited 2016 Nov 17]; 3(2):3 5. Available from: http://www.fisioterapiaesaudefuncional.ufc.br/index. php/fisioterapia/article/view/489/pdf 
26. Davis DHJ, Smith R, Brown A, Rice B, Yin Z, Delpech V. Early diagnosis and treatment of HIV infection: magnitude of benefit on short-term mortality is greatest in older adults. Age Ageing [Internet]. 2013 Jul; [cited 2016 Nov 17]; 42(4):520-6. Available from: http://www.ncbi.nlm.nih.gov/ pmc/articles/PMC3684112/?tool=pubmed. DOI: 10.1093/ageing/aft052

27. Yazdanpanah Y, Lange J, Gerstoft J, Cairns G. Earlier testing for HIVhow do we prevent late presentation? Antivir ther [Internet]. 2010; [cited 2016 Nov 17]; 15 Suppl 1:17-24. Available from: http://www.ncbi.nlm. nih.gov/pubmed/20442457. DOI: 10.3851/IMP1526

28. Backes DS, Backes MS, Erdmann AL, Büscher A. O papel profissional do enfermeiro no Sistema Único de Saúde: da saúde comunitária à estratégia de saúde da família. Ciênc Saúde Coletiva [Internet]. 2012 Jan; [cited 2016 Nov 17]; 17(1):223-30. Available from: http://www.scielo. br/scielo.php?script=sci_arttext\&pid=S1413-81232012000100024

29. Silva VG, Motta MCS, Zeitoune RCG. A prática do enfermeiro na Estratégia Saúde da Família: o caso do município de Vitória/ES. Rev Eletr Enferm [Internet].2010; [cited 2016 Nov 17]; 12(3):441-8. Available from: https://www.fen.ufg.br/fen_revista/v12/n3/v12n3a04.htm

30. Roecker S, Budó MLD, Marcon SS. Trabalho educativo do enfermeiro na Estratégia Saúde da Família: dificuldades e perspectivas de mudanças. Rev Esc Enferm USP [Internet].2012 Jun; [cited 2016 Nov 17]; 46(3):641-9. Available from: http://www.scielo.br/pdf/reeusp/v46n3/16.pdf
31. Zambenedetti G, Both NS. Problematizando a atenção em HIV-Aids na Estratégia Saúde da Família. Rev Polis Psique [Internet]. 2012; [cited 2016 Nov 17]; 2(1):99-119. Available from: http://seer.ufrgs.br/index. php/PolisePsique/article/view/30512/25707

32. Uribe AF, Orcasita LT. Evaluación de conocimientos, actitudes, susceptibilidad y autoeficacia frente al $\mathrm{VIH} /$ sida en profesionales de la salud. Av Enferm [Internet]. $2011 \mathrm{Jul} / \mathrm{Dec}$; [cited $2016 \mathrm{Nov}$ 17]; 29(2):271-84. Available from: http://www.scielo.org.co/scielo. php?script=sci_arttext\&pid=S0121-45002011000200007

33. Navarro AMA, Bezerra VP, Oliveira DA, Moreira MAS, Alves MSCF, Gurgel SN. Representações sociais do HIV/AIDS: percepção dos profissionais da atenção primária à saúde. Rev Pesqui Cuid Fundam Online [Internet]. 2011 Dec; [cited 2016 Nov 17]; 3(5 Suppl):92-9. Available from: http://www.seer.unirio.br/index.php/ cuidadofundamental/article/view/1966/pdf_529

34. Silva O, Guilhem D, Bampi LNS. Trinta minutos que mudam a vida: Teste Rápido Anti-HIV Diagnóstico para parturientes e acesso ao pré-natal. Enferm Foco [Internet]. 2012; [cited 2016 Nov 17]; 3(4):211-5. Available from: http://revista.portalcofen.gov.br/index.php/enfermagem/article/ viewFile/387/178

\footnotetext{
* Section of the master's thesis "Mapping the implementation of rapid HIV testing in the Family Health Strategy", defended and approved in the Graduate Program in Nursing of the Federal University of Rio Grande do Norte in 2016 by the first author with tutoring by the last author. The second author contributed intellectually only with the elaboration of this publication.
} 